\title{
URGENSI PENERAPAN RESPONSIBILTY TO PROTECT GUNA MENANGANI PEMERKOSAAN SISTEMATIK DALAM KONFLIK BERSENJATA INTERNASIONAL
}

\author{
Rahadyan Fajar Harris", Inaz Indra Nugroho, Farabi As-Sabili \\ Universitas Airlangga, Universitas Diponegoro, Universitas Pancasila \\ *Correspondent Email : rahadyan.fajar.harris-2019@fh.unair.ac.id
}

Naskah diterima: 29/10/2021, Revisi: 15/11/2021, Disetujui: 31/12/2021

\begin{abstract}
Abstrak
Kepenulisan ini bertujuan untuk mengetahui urgensi penerapan prinsip Tanggung Jawab untuk melindungi (Responsibility to Protect) dalam menangani kasus pemerkosaan sistematik yang terjadi di wilayah yang sedang mengalami sengketa konflik bersenjata internasional (International armed conflict). Metode penelitian yang digunakan adalah yuridis normatif dengan pendekatan perundang-undangan (statute approach) dan pendekatan konseptual (conceptual approach). Penelitian ini menemukan fakta bahwa pemerkosaan sistematik telah menjadi strategi peperangan selama berabad-abad dengan wanita dan anak perempuan sebagai korbannya. PBB memperkirakan lebih dari 60.000 wanita diperkosa selama perang saudara di Sierra Leone (1991-2002), 40.000 di Liberia (1989-2003), 60.000 di bekas Yugoslavia (1992-1995), dan setidaknya 200.000 di Republik Demokratik Kongo sejak 1998. Sehingga secara yuridis, pemerkosaan sistematik tergolong ke dalam pelanggaran berat (grave breach) dalam kerangka hukum humaniter Internasional. Selain itu, tergolong pula ke dalam kejahatan perang (war crimes) ataupun kejahatan terhadap kemanusiaan (crime against humanity) berdasarkan Statuta Roma 1998. Oleh karena itu, penelitian ini merekomendasikan penerapan prinsip Responsibility to Protect sebagai alternatif penyelesaian kasus pemerkosaan sistematik pada sengketa konflik bersenjata Internasional. Kebaruan penelitian ini ialah penyajian analisis topik pemerkosaan sistematik dalam sengketa konflik bersenjata internasional melalui kerangka hukum humaniter internasional, yang mana belum banyak diteliti di Indonesia. Dalam penelitian ini dapat disimpulkan, bahwasanya meskipun telah terdapat instrumen hukum internasional, masih terdapat banyak pelanggaran berat, kejahatan perang, ataupun kejahatan terhadap kemanusiaan yang terjadi dalam sengketa konflik bersenjata Internasional. Oleh karena itu, penerapan prinsip Responsibility to Protect menjadi suatu urgensi guna mendorong tanggung jawab negara dalam memberikan perlindungan terhadap korban pemerkosaan sistematik dengan sistem intervensi dalam rangka mencegah dan menghentikan pelanggaran berat yang terjadi dalam konflik bersenjata internasional.
\end{abstract}

\section{How to cite:}

Harris, R. F., Nugroho, I., \& Assabili, F. (2021). Urgensi Penerapan Responsibility to Protect Guna Menangani Pemerkosaan Sistematik Dalam Konflik Bersenjata Internasional. Ikatan Penulis Mahasiswa Hukum Indonesia Law Journal, 1(2)

Diterbitkan oleh:

Ikatan Penulis Mahasiswa Hukum Indonesia

IPMHI Law Journal

${ }^{\circledR} 2021$ Author 
Kata Kunci : Hukum Humaniter Internasional; Konflik Bersenjata Internasional; Pemerkosaan Sistemik; Responsibility to Protect.

\section{PENDAHULUAN}

\section{Latar Belakang}

Perang dunia ke-2 tentu saja membuka mata banyak negara-negara di dunia terkait lemahnya perlindungan terhadap warga sipil ketika peperangan antar negara sedang berlangsung. Bukti nyata lemahnya perlindungan terhadap warga sipil tersebut dapat dilihat pada masa pendudukan Uni Soviet di Jerman pada perang dunia ke-2 tahun 1945. Diketahui segera setelah perang tersebut berlangsung, 1 dari 3 wanita Berlin diperkosa oleh pasukan sekutu yang sebagian besar diantaranya merupakan Red Army (tentara merah) Uni Soviet, dimana diketahui sebanyak 10.000 wanita di Berlin meninggal dunia akibat serangan seksual. Atas insiden perkosaan yang dilakukan oleh tentara merah tersebut, banyak wanita Berlin yang lebih memilih untuk mengakhiri hidupnya setelah pemerkosaan berakhir. Beberapa diantaranya dipaksa untuk mengakhiri hidupnya oleh ayah mereka karena tidak menghormati tentara merah, dan beberapa diantaranya ditembak dan dibunuh oleh suami mereka karena telah menyetujui hubungan seksual dengan tentara sekutu (tentara merah). ${ }^{1}$

Perang dunia ke-2 yang menimbulkan banyak korban jiwa termasuk warga sipil tersebut menumbuhkan kesadaran seluruh negara untuk melindung warga sipil dalam peperangan, oleh karena nya negara-negara bersepakat untuk membuat Konvensi Jenewa 1949 tentang Perlindungan Korban Perang. Konvensi Jenewa 1949 terdiri atas 4 konvensi, dimana konvensi ke IV bertujuan untuk memberikan perlindungan terhadap orang sipil di waktu perang.

Meskipun telah dikeluarkannya konvensi jenewa IV, namun instrumen ini dirasa belum efektif karena pada kenyataanya masih banyak pelanggaran yang dilakukan oleh pihak-pihak yang terlibat dalam konflik bersenjata internasional, serta minimnya bentuk pertanggungjawaban yang diterima oleh pelaku. Sebagai contoh yakni insiden pemusnahan massal yang terjadi di Rwanda, BosniaHerzegovina, dan Kosovo pada akhir tahun 1990-an.

Setelah diselesaikannya kasus tersebut dengan dibentuknyaPengadilan Kejahatan Internasional untuk eks Rezim Yugoslavia (International Criminal for the Former Yugoslavia) melalui resolusi 808 tahun 1993, dan Pengadilan Kejahatan Internasional untuk Rwanda (International Criminal Tribunal for Rwanda) melalui resolusi 955 tahun 1994, PBB merasa membutuhkan suatu peradilan yang memiliki kewenangan untuk mengadili para pelaku yang telah melakukan tindakan tidak manusiawi tersebut pada waktu perang antar negara, sehingga dalam hal ini Perserikatan Bangsa-Bangsa membentuk Pengadilan Pidana Internasional (International Criminal Court) di Roma dengan Statuta Roma 1998 sebagai dasar hukum keberlakuan Pengadilan Pidana Internasional.

Dalam Konvensi Jenewa 1949 disebutkan bahwa peperangan yang terjadi antara 2 negara atau lebih dikenal juga dengan sebutan Konflik Bersenjata Internasional (International Armed Conflict). Sebagai salah satu instrumen hukum internasional yang berfungsi untuk memberikan perlindungan kepada warga sipil,

\footnotetext{
${ }^{1}$ Hsu-Ming Teo. (1996). The Continuum of Sexual Violence in Occupied Germany, 1945-49. Women's History Review, 5(2), 191. Doi: 10.1080/09612029600200111
} 
Konvensi Jenewa menggolongkan pemerkosaan yang terjadi pada konflik bersenjata internasional sebagai bentuk daripada kejahatan perang (war crimes) ataupun pelanggaran berat (grave breaches). Sementara disamping itu Statuta Roma 1998 yang berfungsi sebagai dasar hukum pelaksanaan Pengadilan Pidana Internasional menggolongkan pemerkosaan yang terjadi pada konflik bersenjata internasional sebagai bentuk daripada kejahatan terhadap kemanusiaan (crime against humanity), kejahatan perang, dan juga pelanggaran berat.

Peristiwa pemusnahan massal yang terjadi di Bosnia-Herzegovina dan Rwanda tersebut merupakan salah satu bukti nyata atas kegagalan komunitas internasional dalam melindungi populasi dari kejahatan massal. Kegagalan komunitas internasional tersebut didasari faktor adanya dua persepsi yang berbeda dalam anggota PBB terkait pentingnya pelaksanaan intervensi bagi komunitas internasional, dimana satu pihak berpegang teguh pada gagasan tradisional yang tercantum dalam Peace of Westaphalia (Perjanjian Westaphalia) terkait kedaulatan negara (state sovereignty). Sedangkan pihak di sisi lain mendukung pentingnya peran komunitas internasional dalam melakukan intervensi terhadap suatu negara yang sedang mengalami kejahatan massal. ${ }^{2}$ Peristiwa pemusnahan massal yang terjadi di Bosnia-Herzegovina yang memakan korban jiwa berjumlah 8000 orang Bosnia muslim pada tahun 1995, dan Rwanda yang memakan korban jiwa berjumlah 800.000 orang suku Tutsi dan Hutu Moderat pada tahun 1994 tersebut cukup menyita perhatian beberapa pihak, diantaranya yakni Sekretaris Jendral Kofi Annan. Atas insiden tersebut Annan mendesak kepada komunitas internasional untuk segera menemukan cara dalam mengatasi permasalahan kejahatan massal yang terjadi di beberapa negara, disamping itu Annan juga mengajukan pertanyaan pada pidatonya di sidang umum PBB tahun 2000 yang menyatakan: ${ }^{3}$

"...if humanitarian intervention is, indeed, an unacceptable assault on sovereignty, how should we respond to a Rwanda, to a Srebrenica to gross and systematic violations of human rights that affect every precept of our common humanity"

Menanggapi pertanyaan yang diutarakan oleh Annan, Pemerintah Kanada membentuk sebuah badan pada tahun 2001 bernama International Commission on Intervention and State Sovereignty dengan diketuai oleh Gareth Evans dan Mohammed Sahnoun. Badan ini menyajikan laporan dengan judul "Responsibility to Protect" kepada dewan komisaris PBB, dimana hal tersebut merupakan langkah awal terbentuknya norma Responsibility to Protect. ${ }^{4}$

Tanggung Jawab untuk melindungi (Responsibility to Protect) atau dikenal dengan sebutan R2P merupakan suatu norma internasional yang bertujuan untuk mencegah terjadinya kejahatan massal yang meliputi pemusnahan massal (genocide), kejahatan perang (war crimes), pembersihan etnis (ethnic cleansing), dan kejahatan terhadap kemanusiaan (crimes against humanity). ${ }^{5}$

\footnotetext{
${ }^{2}$ Okta Maryana Dewi. Analisis Penerapan Responsibility to Protect (R2P) dalam Penyelesaian Krisis Kemanusiaan di Rakhine: Studi Kasus Rohingya (2012-2017). Skripsi Universitas Islam Indonesia. Yogyakarta. hlm. 37.

${ }^{3}$ Ibid., hlm. 38.

${ }^{4}$ Ibid., hlm. 39-40.

${ }^{5}$ Global Centre For The Responsibility to Protect. What Is R2P?. <https://www.globalr2p.org/whatisr2p/\#: :text=The\%20 concept $\% 20$ emerged $\% 20$ in $\% 20$ response,concept $\% 20$ of $\% 20 \mathrm{R} 2 \mathrm{P} \% 20 \mathrm{durig}$ \%202001> . (Diakses 28 Januari 2022).
} 
Berbeda dengan perlindungan hukum yang diatur dalam Konvensi Jenewa 1949 dan Protokol Tambahan I dan II tahun 1977, serta Statuta Roma tahun 1998, Prinsip Responsibility to Protect menawarkan 3 bentuk upaya yang dapat dilakukan ketika terjadinya kejahatan massal, yakni Responsibility to Prevent, Responsibility to React, dan Responsibility to Re-Build. ${ }^{6}$ Secara garis besar Responsibility to Protect mewajibkan kepada setiap negara untuk memikul tanggung jawab dalam melindungi populasi negara nya dari kejahatan massal, mewajibkan kepada komunitas internasional untuk memikul tanggung jawab cadangan dalam membantu negara-negara untuk memenuhi tugas nya tersebut dan melakukan intervensi apabila suatu negara tidak mampu untuk melindungi rakyatnya. ${ }^{7}$

Namun demikian, norma Responsibility to Protect masih belum dapat menjawab keseluruhan permasalahan kejahatan perang ataupun kejahatan terhadap kemanusiaan yang terjadi di tengah konflik bersenjata internasional. Meskipun norma Responsibility to Protect yang dikembangkan oleh International Commission on Intervention and State Sovereignty dianggap cukup komperhensif karena menawarkan 3 upaya yang dapat dilakukan ketika terjadinya kejahatan massal. Akan tetapi, tidak sedikit negara yang mengutarakan kekhawatirannya atas implementasi norma tersebut. India, China, Brasil, Rusia, dan Afrika memberikan pandangan skeptis terhadap norma Responsibility to Protect setelah melihat Intervensi yang dilakukan oleh North Atlantic Treaty Organization (NATO) pada konflik politik di Libya tahun $2011 .{ }^{8}$ Selain itu menurut David Vessel, intervensi kemanusiaan sepihak yang dilakukan oleh komunitas internasional di tengah konflik bersenjata internasional dianggap dapat melanggar prinsip kedaulatan negara yang telah diakui sejak lahirnya Peace of Westphalia pada tahun $1648 .{ }^{9}$ Prinsip Responsibility to Protect juga dianggap bertentangan dengan Pasal 2 ayat (7) Piagam PBB, dimana disebutkan bahwa tidak ada satu ketentuan pun dalam Piagam PBB yang memberi kuasa kepada Perserikatan Bangsa-Bangsa untuk mencampuri urusan-urusan yang pada hakekatnya termasuk urusan dalam negeri suatu negara, atau mewajibkan anggota-anggota nya untuk menyelesaikan urusanurusan tersebut. ${ }^{10}$

\footnotetext{
${ }^{6}$ Dewi, Op.Cit, hlm. 41.

${ }^{7}$ Dr Hugh Breaky, Dr Angus Francis, Professor Vesselin Popovski, dkk. (2012). Enhancing Protection Capacity: Policy Guide to the Responsibility to Protect and the Protection of Civilians in Armed Conflicts. Policy Guide, hlm. ix.

${ }^{8}$ Sefriani. (2020). The Implementation Of The First Pillar Of Responsibility To Protect In Indonesia:

Critical Analysis Of Law On Social Conflict Management. Jurnal Hukum Ius Quia Iustum, 27(1),

8. Doi: 10.20885/iustum.vol27.iss1.art1

${ }^{9}$ Ibid.

${ }^{10}$ Piagam Perserikatan Bangsa-Bangsa, article 2, paragraf 7.
} 
Oleh karena nya, dalam jurnal ini akan ditelaah lebih lanjut bagaimana seyogyanya model norma Responsibility to Protect yang seharusnya diimplementasikan oleh pihak yang terlibat dalam konflik bersenjata internasional, komunitas internasional, dan negara anggota PBB sebagaimana amanat piagam PBB. Dalam hal ini, norma Responsibility to Protect merupakan suatu diskursus baru yang sangat berpotensi untuk dapat menjadi pendorong resolusi konflik bersenjata internasional. Lebih lanjut, jurnal ini akan mendalami mengenai perkembangan dan eksistensi pengaturan norma Responsibility to Protect ataupun instrument hukum internasional terkait yang telah ada guna menelaah kepastian hukumnya.

\section{Perumusan Masalah}

1. Bagaimana Regulasi Hukum Humaniter Internasional Terhadap Kejahatan Pemerkosaan Sistemik di Masa Konflik Bersenjata Internasional yang Telah Ada Sejauh Ini?

2. Bagaimana model penggunaan Prinsip Responsibility to Protect (R2P) dalam menyelesaikan Kejahatan Pemerkosaan Sistemik di Masa Konflik Bersenjata Internasional?

\section{METODE}

Metode penelitian yang digunakan adalah penelitian hukum yuridis normatif. Penelitian yuridis normatif merupakan penelitian hukum kepustakaan yang dilakukan dengan cara meneliti bahan-bahan pustaka atau data sekunder belaka. ${ }^{11}$ Jenis data yang digunakan meliputi bahan hukum primer seperti konvensi internasional yang memiliki keterkaitan dengan pemerkosaan sistematik pada waktu konflik bersenjata internasional (International Armed Conflict), bahan hukum sekunder, dan bahan hukum tersier. Sehubungan dengan jenis penelitian yang digunakan adalah yuridis normatif, maka pendekatan yang digunakan dalam tulisan ini adalah pendekatan perundang-undangan (statute approach) dan pendekatan konseptual (conceptual approach). Pendekatan perundangundangan (statute approach) merupakan pendekatan yang mengutamakan penggunaan bahan hukum berupa peraturan perundang-undangan ataupun konvensi internasional yang memiliki keterkaitan dengan judul karya tulis ini sebagai bahan acuan dalam melakukan penelitian. Pendekatan konseptual (conceptual approach) merupakan pendekatan yang menitikberatkan pada pemberian sudut pandang analisa penyelesaian permasalahan dalam penelitian hukum dilihat dari aspek konsep-konsep hukum yang melatarbelakanginya, atau dilihat dari nilai-nilai yang terkandung dalam penormaan sebuah peraturan kaitannya dengan konsepkonsep yang digunakan.

\section{HASIL PENELITIAN DAN PEMBAHASAN}

\section{REGULASI HUKUM HIMANITER INTERNASIONAL TERHADAP KEJAHATAN PEMERKOSAAN SISTEMATIK DI MASA KONFLIK BERSENJATA INTERNASIONAL}

Konflik bersenjata yang terjadi di seluruh dunia merenggut banyak nyawa penduduk sipil yang terjebak di wilayah konflik tersebut. Konflik bersenjata sendiri dibagi menjadi dua, yaitu konflik bersenjata internasional dan konflik bersenjata non-internasional. Pengertian dari konflik bersenjata

\footnotetext{
${ }^{11}$ Bambang Sunggono, Metodologi Penelitian Hukum, (Jakarta: Raja Grafindo Persada, 2003), hlm.
} 13. 
internasional adalah konflik atau sengketa yang terjadi antara dua atau lebih negara, sedangkan konflik bersenjata non-internasional adalah konflik atau sengketa yang peristiwanya terjadi dalam satu negara (bersifat internal). Konflik bersenjata non-internasional dapat terjadi antara pemberontak terorganisir dengan pemerintahan negara yang bersangkutan. ${ }^{12}$

Pengaturan terkait konflik bersenjata internasional diatur dalam Common Article 2 dari Konvensi Jenewa 1949 atau Pasal 1 (4) dari Protokol Tambahan I 1977. Common Article 2 Konvensi Jenewa 1949 menyatakan bahwa hukum humaniter internasional berlaku ke pihak-pihak yang melakukan peperangan atau konflik bersenjata lainnya tanpa melihat alasan terjadinya konflik bersenjata. Dilanjutkan dengan pernyataan hukum humaniter akan berlaku terhadap negara yang melakukan peperangan walaupun salah satu negara atau seluruhnya tidak mengakui konflik mereka sebagai bagian dari konflik bersenjata. Protokol Tambahan I Tahun 1977 meluaskan arti dari konflik bersenjata dengan mengakui orang-orang yang berjuang melawan dominasi kolonial, alien occupation, atau rezim rasis dalam rangka menentukan nasib dan membebaskan diri mereka sendiri (wars of national liberation). ${ }^{13}$

Dalam berjalannya konflik, perempuan menjadi kelompok yang rentan mendapat kekerasan dan menjadi target kekerasan. Salah satu jenis kekerasan yang sering didapat adalah kekerasan seksual dalam bentuk pemerkosaan. Tidak ada pengertian resmi terkait pemerkosaan dalam hukum hak asasi manusia internasional maupun hukum humaniter internasional. Namun menurut rumusan International Criminal Tribunal for Rwanda (ICTR) dalam kasus Furundzidja, terdapat beberapa unsur pemerkosaan yaitu

A. Penetrasi seksual walaupun ringan :

1. Dilakukan terhadap anus atau vagina korban dengan penis pelaku atau alat lainnya.

2. Dilakukan terhadap mulut korban dengan penis pelaku.

B. Penetrasi yang dilakukan dengan kekerasan, pemaksaan, tekanan, atau ancaman terhadap korban atau orang ketiga. ICTR menyatakan bentuk pemaksaan sebagai "berbagai macam pemerasan dan pemaksaan yang mengakibatkan rasa keputusasaan dan ketakutan serta paksaan tersebut dilakukan dengan keadaan tertentu misal saat terjadi konflik bersenjata atau terdapat kehadiran militer" ${ }^{14}$

Pemerkosaan dalam konflik bersenjata seringkali dilakukan secara sistemik dengan tujuan tertentu. Astrid Aa Ffjes berpendapat bahwa tujuan dari pemerkosaan sistemik adalah untuk mengintimidasi masyarakat sipil agar meninggalkan rumah-rumah mereka, mempermalukan musuh dengan menunjukkan bahwa mereka telah mendapat kontrol atas perempuanperempuan dari etnis atau wilayah musuh, dan sebagai pemuas nafsu pasukan bersenjata yang diyakini dapat merangsang keberanian di medan perang. Eksploitasi perempuan yang dipaksa menjadi pekerja seks dilakukan dengan tujuan : untuk memberikan dukungan moral (moral support) ke komandan

\footnotetext{
12 Deny Ramdhany dkk,2015,Konteks dan Perspektif Politik Terkait Hukum Humaniter Internasional Kontemporer, PT Raja Grafindo Persada,jakarta,hlm:255

${ }^{13}$ Protocol Tambahan I Tahun 1977, article 1, paragraf 4.

${ }^{14}$ Lihat Pedoman Unsur-unsur Tindak Pidana Pelanggaran Hak Asasi Manusia Yang Berat Dan Pertanggungjawaban Komando, Mahkamah Agung R.I. 2006, hlm. 44.
} 
dan prajurit, serta penyerangan seksual massal ke perempuan dengan tujuan kehamilan paksa (forced pregnancy). Kehamilan paksa dilakukan sebagai cara untuk membuat perempuan pihak musuh merasa bersalah dan malu, serta mengintimidasi musuh bahwa keturunan-keturunan mereka yang lahir sudah bukan etnis murni lagi. ${ }^{15}$ Pasal 7 ayat (2) bagian (f) mengartikan forced pregnancy sebagai persalinan tidak sah oleh wanita yang dihamili secara paksa dengan tujuan untuk mempengaruhi jumlah (komposisi) etnis dari setiap populasi atau bertujuan melakukan pelanggaran berat lain terhadap hukum internasional. ${ }^{16}$

Dengan besarnya kemungkinan dapat terjadi pemerkosaan sistemik dalam peperangan, maka dilakukanlah berbagai perumusan dan pengesahan instrumen hukum internasional yang mengatur terkait perlindungan perempuan dari kekerasan seksual termasuk pemerkosaan sistemik dalam konflik bersenjata internasional. Salah satunya adalah Konvensi Jenewa Tahun 1949 dan Protokol Tambahan Tahun 1977. Kedua instrumen hukum internasional ini mengatur tanggung jawab serta kewajiban kepada pihakpihak yang bersengketa agar secara efektif melaksanakan perlindungan terhadap perempuan yang terdampak konflik bersenjata internasional. Konvensi Jenewa 1494 sendiri terdiri dari empat konvensi, yaitu:

1) Konvensi mengenai perbaikan keadaan anggota angkatan perang yang luka dan sakit di medan pertempuran darat;

2) Konvensi mengenai perbaikan keadaan anggota angkatan perang di laut yang luka, sakit dan korban karam;

3) Konvensi mengenai perlakuan tawanan perang

4) Konvensi mengenai perlindungan orang-orang sipil di waktu perang; Perlindungan perempuan di masa konflik bersenjata internasional diatur dalam konvensi keempat. Hal ini dikarenakan perempuan juga digolongkan sebagai masyarakat sipil yang terkena dampak dari konflik bersenjata internasional. Konvensi Jenewa keempat memberikan pengaturan khusus terhadap perempuan terkait dengan perlindungan dari kekerasan seksual terhadapnya. Pengaturan khusus ini disebutkan dengan tegas dalam Pasal 27 Paragraf kedua ${ }^{17}$. Bunyi pasal tersebut memberikan garis batas jelas terkait larangan untuk melakukan tindakan kekerasan seksual terhadap perempuan dalam konflik bersenjata. Dari pasal tersebut, terdapat dua tindakan yang tidak diperbolehkan untuk dilakukan oleh pihak-pihak yang berkonflik terhadap perempuan sipil, yaitu:

1). Tidak dibolehkannya melakukan tindakan kekerasan seksual karena berupa serangan atas kehormatan perempuan.

2). Tidak dibolehkannya melakukan serangan yang terdapat unsur pelanggaran kesusilaan terhadap perempuan. ${ }^{18}$

Frasa "serangan atas kehormatan perempuan" dan "pelanggaran kesusilaan terhadap perempuan" dalam Pasal 27 tidak hanya terbatas pada

\footnotetext{
${ }^{15}$ Nur Iman Subono, Konflik Bersenjata Kekerasan Militer dan Perempuan (Perempuan di Wilayah Konflik),Jurnal Perempuan, Yayasan Jurnal Perempuan, Jakarta, 2002, hlm. 116

${ }^{16}$ Statuta Roma 1998.

${ }^{17}$ Lihat, Pasal 27 ayat (2) menyatakan: "Women shall be especially protected against any attack on their honour, in particular against rape, enforced prostitution, or any form of indecent assault.", dalam, International Committee of the Red Cross (ICRC), Geneva Convention Relative to the Protection of Civilian Persons in Time of War (Fourth Geneva Convention), 12 August 1949, 75 UNTS 287, Article 27, Par. 2.

${ }^{18}$ Hilda. "Perlindungan Hukum Humaniter Terhadap Perempuan dari Kekerasan Seksual dalam Sengketa Bersenjata". Syiar Hukum, Vol. XII, No. 2, Juli 2010. Hlm. 106
} 
pemerkosaan. Frasa ini mencakup seluruh bentuk kekerasan seksual yang dapat terjadi di wilayah konflik bersenjata. Bentuk kekerasan seksual ini dapat berupa fisik maupun non fisik (psikologis).

Selain Konvensi Jenewa 1949, upaya perlindungan terhadap perempuan dalam konflik bersenjata diatur dalam Protokol Tambahan Tahun 1977 yang terbagi menjadi dua protokol. Protokol Tambahan I tentang perlindungan korban pada sengketa bersenjata internasional dan Protokol Tambahan II tentang perlindungan korban pada sengketa bersenjata noninternasional. Kedua protokol ini merupakan pelengkap dan penyempurna substansi serta isi dari Konvensi Jenewa 1949. Perbedaan kedua protokol ini terletak dalam jenis konflik bersenjata yang diatur di dalamnya, sehingga untuk perlindungan perempuan dalam konflik bersenjata internasional diatur secara khusus dalam Protokol Tambahan I.

Pengaturan terkait perlindungan perempuan dari kekerasan seksual pada masa konflik bersenjata internasional dalam Protokol Tambahan I Tahun 1977 dapat mengacu ke dua pasal yakni Pasal 75 ayat (2) huruf (b) dan Pasal 76 ayat (1). Pasal 75 ayat (2) huruf (b) menyatakan bahwa:

Pasal 75 protokol ini memberikan penegasan dari Konvensi Jenewa 1949 akan adanya larangan terhadap perilaku yang mempermalukan dan merendahkan martabat perempuan, termasuk pemerkosaan. Penjelasan bentuk kekerasan seksual dalam pasal ini adalah perbuatan yang tidak menghormati perempuan, pelacuran secara paksa, dan setiap serangan yang berbentuk tidak senonoh. Maka dari itu, tindakan-tindakan tersebut dilarang dilakukan oleh pihak manapun selama konflik bersenjata internasional terjadi dalam kondisi dan waktu apapun. Dalam Pasal 76 ayat (1) ditegaskan kembali Pasal 27 ayat (2) Konvensi Jenewa 1949 keempat yaitu jaminan penghormatan terhadap perempuan di konflik bersenjata internasional. Perbedaan jaminan penghormatan Protokol Tambahan ini dibanding Konvensi Jenewa 1949 keempat terdapat dalam "the object of special respect". Pasal ini menyatakan perempuan berhak untuk mendapat penghormatan khusus dari pihak manapun.

Regulasi tersebut, sebagian besar mengatur terkait kekerasan seksual secara umum. Walaupun begitu, pemerkosaan dalam konflik bersenjata internasional tetap dapat dicegah dan ditindaklanjuti melalui regulasi tersebut. Sebab, pemerkosaan penodaan penghormatan atas martabat perempuan. Namun terkadang, dalam penegakan hukumnya masih sulit dicapai karena negara pihak dalam konflik bersenjata internasional seringkali tidak mampu melindungi warga sipilnya. Oleh karena itu, diperlukan suatu model untuk dapat membantu penegakan hukum ini.

2. MODEL PENGGUNAAN PRINSIP RESPONSIBILITY TO PROTECT (R2P) MENYELESAIKAN KEJAHATAN PEMERKOSAAN SISTEMATIK DI MASA KONFLIK BERSENJATA INTERNASIONAL

\section{a. Konsepsi Responsibility to Protect (R2P) Sebagai Resolusi Konflik Bersenjata Internasional}

Pada analisis sebelumnya telah disebutkan bahwa pemerkosaan sistematik merupakan kejahatan perang sekaligus kejahatan terhadap kemanusiaan yang terjadi akibat gagalnya suatu negara melindungi warga sipilnya dalam masa konflik bersenjata internasional. Oleh karena itu pada tahun 2005, PBB menggelar Konferensi Tingkat Tinggi (KTT) Dunia yang 
salah satu capaian pentingnya adalah kesepakatan bulat di antara para pemimpin dunia bahwa semua negara memiliki tanggung jawab untuk melindungi rakyatnya dari 4 jenis kejahatan kekejaman massal, yakni pemusnahan massal/genosida, kejahatan perang, kejahatan terhadap kemanusiaan, pembersihan etnis. ${ }^{19}$

Kesepakatan inilah yang dituangkan dalam Paragraf 138,139,140 Dokumen Hasil KTT Dunia di New York bulan September 2005, dan kemudian disebut Responsibility to Protect $(\mathrm{R} 2 \mathrm{P})^{20}$. Sehingga, para negara peserta bersepakat untuk siap mengambil tindakan kolektif ketika suatu negara gagal bertanggung jawab melindungi rakyatnya dari empat jenis kejahatan tersebut. Selain itu, didefiniskan pula tiga tanggungjawab negara yang harus dipenuhi oleh negara:

1. Responsibility to Prevent : merupakan tanggung jawab negara untuk mencegah terjadinya kejahatan kemanusiaan di wilayahnya. Hal ini dilakukan dengan mengatasi akar-akar permasalahan konflik seperti distribusi sumber daya yang tidak merata sehingga menimbulkan kecemburuan sosial, kemiskinan, dan tekanan politik. Penyelesaian permasalahan dapat dilakukan melalui upaya-upaya diplomatik, upaya ekonomi, dan upaya militer untuk menghambat konflik agar tidak meluas;

2. Responsibility to react: Tanggung jawab untuk bereaksi atau merespon situasi-situasi ketika pembunuhan massal, pembersihan etnis atau kejahatan kemanusiaan telah berlangsung atau akan terjadi. Apabila negara tidak mau atau tidak mampu melindungi penduduk sipilnya sendiri dari pelanggaran hak asasi manusia secara massal yang terjadi di dalam negaranya maka tanggung jawab berpindah pada masyarakat internasional. Hal ini termasuk penggunaan cara-cara militer jika cara-cara damai gagal;

3. Responsibility to rebuild: Tanggung jawab untuk membangun kembali setelah terjadinya intervensi militer Negara dan komunitas internasional bertanggungjawab untuk memberikan bantuan kepada masyarakat yang telah mengalami kekejaman massal untuk dapat pulih, membangun kembali dan berdamai setelah konflik terjadi

Beberapa tahun setelah kesepakatan KTT Dunia 2005 atas "Responsibility to Protect", sejumlah kemajuan telah dicapai. SekretarisJenderal PBB, Ban-ki Moon, menjelaskan tentang "Responsibility to Protect" dengan memberikan penekanan pada ketiga pilar untuk menerapkan prinsip ini. Ketiga pilar tersebut adalah ${ }^{21}$ :

1. Tanggung jawab negara untuk melindungi rakyatnya sendiri dari pemusnahan massal (genocide), kejahatan perang (war crimes), pembersihan etnis (ethnic cleansing) dan kejahatan terhadap kemanusiaan (crimes against humanity), dan dari segala macam tindakan yang mengarah pada jenis-jenis kejahatan tersebut;

2. Komitmen komunitas internasional untuk membantu negara-negara dalam menjalankan tanggung jawabnya itu;

\footnotetext{
${ }^{19}$ Lihat Alex J. Bellamy dan Tim Dune, "R2P in Theory and Practice", hlm. 34. dalam The Oxford Handbook of the Responsibility to Protect, (Oxford: Oxford University Press, 2006).

${ }^{20}$ Ibid. hlm. 36

${ }^{21} \mathrm{UN}$ General Assembly, Implementing the responsibility to protect : report of the SecretaryGeneral, 12 January 2009, A/63/677, supra note 11-12, hlm. 4, 25 Juli 2012.
} 
3. Tanggung jawab setiap negara anggota PBB untuk merespon secara kolektif, tepat waktu dan tegas ketika suatu negara gagal memberikan perlindungan yang dimaksud.

Ketiga pilar tersebut sama kuat dan pentingnya. Namun, dimensi yang paling penting dari R2P adalah pencegahan terhadap pemusnahan massal dan berbagai kejahatan kemanusiaan lainnya. Harapan dari komunitas internasional ini supaya dunia tidak akan pernah lagi menyaksikan pemusnahan massal, kejahatan perang, kejahatan terhadap kemanusiaan atau pembasmian etnis. ${ }^{22}$

\section{b. Model Implementasi Responsibility to Protect (R2P) terhadap} Pencegahan dan Penanganan Pemerkosaan Sistematik

Pada analisis sebelumnya, telah dijelaskan tiga pilar utama dari R2P. Dalam laporan Sekjen PBB, Ban Ki Moon, tahun 2009 yang berjudul Responsibility to Protect: Timely and Decisive Response ${ }^{23}$, Ban Ki Moon menekankan bahwa pilar pertama dan pilar kedua dihubungkan dengan pencegahan sedangkan pilar ketiga dihubungkan dengan respon. Namun di dalam praktek, garis pemisahnya tidaklah begitu jelas, karena tindakan di bawah pilar pertama maupun pilar kedua dapat termasuk elemen pencegahan dan sekaligus respon.

Namun apabila ditelaah dari perspektif hukum, R2P yang diadopsi dalam paragraf 138 dan 139 Resolusi Majelis Umum PBB No. A/60/I sesungguhnya bersifat rekomendatif. Dalam hal ini, R2P tidak Legally Binding meskipun memiliki esensi politik dan moral yang krusial dalam penciptaan norma hukum internasional yang baru ${ }^{24}$. Hal ini dikarenakan, R2P hanya menyediakan kerangka bagi digunakannya berbagai sarana yang sudah tersedia untuk mencegah terjadinya kekejaman massal. R2P tidak menciptakan kewajiban baru bagi negara-negara karena mengacu pada kewajiban-kewajiban negara yang sudah diatur dalam hukum internasional yang sudah ada, seperti hukum humaniter internasional dan hukum hak asasi manusia internasional. ${ }^{25}$

Demikian pula, Ban Ki Moon juga mengembangkan R2P dari sekedar prinsip menjadi sebagai kerangka dasar dalam merumuskan kebijakan responsif yang dapat diaplikasikan dalam menangani 4 kejahatan kekejaman massal ${ }^{26}$. Namun, apabila dihubungkan dengan bagaimana R2P dapat menangani kejahatan pemerkosaan sistematik, rekomendasi 3 pilar dari Ban Ki Moon belum dapat mengakomodasikan mekanisme yang rinci terkhusus pada kasus kekerasan seksual di masa peperangan, atau pemerkosaan sistematik. Sehingga, penulis menyarikan dari berbagai pendapat dan rekomendasi ahli atau organisasi internasional terkait yang juga mengkaji keterkaitan kekerasan berbasis gender terhadap implementasi R2P.

a) Pada Tahap Responsibility to Prevent

\footnotetext{
${ }^{22}$ Lily Husni Putri, "Responsibility To Protect Sebagai Doktrin Atau Norma Yang Berkembang Dalam Hukum Internasional”, Kanun: Jurnal Ilmu Hukum No. 65, Th. XVII, April, 2015, hlm. 168.

${ }^{23}$ UN General Assembly, Responsibility to protect: timely and decisive response - Report of the Secretary-General, 25 July 2012, (A/66/874-S/2012/578).

${ }^{24}$ Thomas Ramopoulos, "International Law and the Application of Third Pillar Approach", hlm. 11. dalam Daniel Flott dan Joachim Koops, "The Responsibility to Protect and the Third Pillar: Legitimacy and Operationalization” (eds), (New York: Palgrave Macmillan, 2015).

${ }^{25}$ Lily Husni Putri, Op.Cit., hlm. 170.

${ }^{26}$ Alex J. Bellamy dan Ruben Reike, "The Responsibility to Protect and International Law", Global Responsibility to Protect Vol.2, 2010, hlm. 270.
} 
i. Memberikan dana bantuan pembangunan terhadap negara berkembang demi meningkatkan sumber daya manusia dalam rangka mengatasi pemerkosaan sistematik

Pada negara berkembang, masih terlihat jelas adanya kesenjangan antara retorika dan dukungan finansial dalam rangka pencegahan pemerkosaan di daerah yang mengalami konflik bersenjata internasional. Secara keseluruhan, pemasukan atas bantuan pembangunan yang digunakan untuk mempromosikan pencegahan konflik bersenjata internasional mengalami penurunan. Kondisi tersebut menyebabkan semakin langkanya sumber daya pada negara berkembang, memperburuk kesenjangan pendapatan dalam masyarakat, serta merampas banyak negara berkembang dari kapasitas untuk menerapkan sumber daya yang maksimal dalam rangka pencegahan konflik bersenjata internasional. ${ }^{27}$

ii. Pemberitahuan peringatan dini (early warning system) berbasis gender terhadap wilayah yang sekiranya akan menghadapi konflik bersenjata internasional

Pemberitahuan peringatan dini dapat dimulai dengan melakukan pengumpulan informasi mengenai potensi konflik bersenjata yang akan terjadi di suatu wilayah dengan melibatkan organisasi keperempuanan dalam pengambilan rencana strategi. Selain itu, perlu adanya pemetaan risiko dan potensi ekskalasi konflik di suatu wilayah, dan memberi peringatan dini kepada kelompok-kelompok rentan, seperti perempuan dan anak-anak, serta kaum minoritas. Hal itu kemudian ditindaklanjuti dengan pengungsian populasi tersebut ke shelter atau tempat pengungsian yang aman di bawah penjagaan tentara PBB dan organisasi keperempuanan dan anak, misalnya UNICEF. $^{28}$

iii. Promosi Kesetaraan Gender dalam Struktur Kebijakan Publik dan Birokrasi Pemerintahan suatu Negara

Promosi ini dapat dicapai melalui penerapannya dalam 4 sektor, yakni politik, hukum, ekonomi, dan militer

Pertama, dalam bidang politik, negara dapat meningkatkan komposisi gender yang lebih seimbang dalam parlemen, sehingga peran perempuan sebagai legislator dan pengambil kebijakan menjadi terakomodasikan. Tak hanya itu, pemerintah juga harus memperhatikan pemenuhan hak-hak perempuan dan mendukung pengembangan organisasi politik berbasis keperempuanan. Selain itu, pemerintah juga wajib segera meratifikasi konvensi-konvensi internasional yang bertujuan untuk melindungi perempuan dan anak, misalnya: CEDAW

Kedua, dalam bidang hukum, pemerintah harus meningkatkan pengawasan terhadap jalannya kebijakan publik yang telah diambil dalam bidang politik. Serta menjadikan ratifikasi konvensi-konvensi internasional terkait untuk diintegrasikan ke dalam peraturan

\footnotetext{
27 Gareth J. Evans dan Mohammed Sahnoun, "The Responsibility to Protect: Report of the International Commission on Intervention and State Sovereignty", International Commission on Intervention and State Sovereignty, 2001, hlm. 20.

28 Jennifer Bond dan Laurel Sherret, "A Sight for Sore Eyes: Bringing Gender Vision to the Responsibility to Protect Framework", United Nations International Research and Training Institute for the Advancement of Women, 2006, hlm. 89.
} 
perundang-undangan yang relevan di negara tersebut. Serta, memastikan perempuan ikut terlibat dalam proses penegakan hukum yang adil $^{29}$

Ketiga, dalam bidang ekonomi, pemerintah harus dapat membuka akses terhadap pemenuhan kebutuhan dasar serta pelayanan kesehatan bagi perempuan, khususnya mengenai pelayanan kesehatan reproduksi. Serta, mendorong pemberdayaan perempuan secara ekonomi. Selain itu, perlu pula dilakukan penghapusan diskriminasi terhadap perempuan di bidang ketenagakerjaan. ${ }^{30}$

Keempat, dalam bidang militer, pemerintah bersama kemiliteran harus menguatkan peraturan militer dan peraturan peperangan yang melarang penyerangan terhadap non-kombatan, yakni warga sipil. Pihak militer juga harus menghapus impunitas terhadap pelanggar hukum perang/penjahat perang, dan menetapkan mekanisme peradilan bagi para penjahat perang

b) Pada Tahap Responsibility to React

i. Kebijakan Zero Tolerance terhadap pelaku kekerasan seksual Hal ini dapat mengacu pada Poin 11 Resolusi 1325 Dewan Kemanan PBB yang menekankan penuntutan tanpa impunitas dan penghapusan amnesti bagi para pelaku kekerasan seksual di masa konflik bersenjata $^{31}$. Selain itu juga, Poin 7 Resolusi 1820 Dewan Keamanan PBB juga menguatkan Resolusi 1325, yakni dengan menekankan penerapan kebijakan tanpa toleransi/Zero Tolerance terhadap eksploitasi dan pelecehan seksual dalam operasi pemeliharaan perdamaian PBB

ii. Penghapusan Impunitas terhadap pelaku dan penanggung jawab militer

Hal ini merupakan penerapan dari ketentuan Pasal 27 Statuta Roma, yang menyatakan bahwa pejabat negara akan bertanggung jawab terhadap segala tindakan yang dilakukannya atas nama negara, pejabat negara, termasuk pejabat yang menikmati imunitas personal ${ }^{32}$. Demikian juga Pasal 28 Statuta Roma mengatur bahwa seorang atasan baik dalam ruang lingkup militer ataupun sipil harus bertanggung jawab secara pidana ketika terjadi kejahatan dalam yurisdiksi ICC yang dilakukan anak buahnya ${ }^{33}$. Pasal ini dimaksudkan untuk menghapuskan praktek impunitas

Hal ini juga dikuatkan dengan ketentuan Poin 11 Resolusi 1325 Dewan Keamanan PBB yang menyatakan untuk Menekankan tanggung jawab semua Negara untuk mengakhiri impunitas dan menuntut mereka yang bertanggung jawab atas genosida, kejahatan terhadap kemanusiaan, dan kejahatan perang termasuk yang

\footnotetext{
29 United Nations Development Programs, "Gender Equality and Democratic Government", $<$ https://www.eurasia.undp.org/content/rbec/en/home/gender-equality/democraticgovernance.html>, diakses pada 3 Februari 2022.

${ }^{30}$ Canadian international Development Agency, "CIDA's Policy on Gender Equality”, (Quebec: Canadian International Development Agency, 1999), hlm. 13.

${ }^{31}$ UN Security Council, Security Council resolution 1325 (2000) [on women and peace and security]. 31 October 2000, S/RES/1325 (2000).

${ }^{32}$ UN General Assembly, Rome Statute of the International Criminal Court (last amended 2010), 17 July 1998. Art. 27.

${ }^{33}$ Ibid. Article. 28.
} 
berkaitan dengan kekerasan seksual dan kekerasan lainnya terhadap perempuan dan anak perempuan

iii. Penuntutan ke International Criminal Court (ICC)

ICC berwenang juga mengadili kasus pemerkosaan secara sistematik, negara peserta ICC atau yang mengakui yurisdiksi ICC dapat menyerahkan kasusnya ke ICC untuk diadili. ICC akan melakukan sidang terhadap subjek hukum individu (bukan negara), baik sipil maupun militer. Dalam Pasal 7 ayat (1) g Statuta Roma, ditegaskan bahwa kekerasan seksual merupakan kejahatan terhadap kemanusiaan dan kejahatan perang ${ }^{34}$. Selain itu, pemerkosaan sistemik sebagai bagian dari kekerasan seksual yang merupakan bagian dari kejahatan perang diatur pada Pasal 8 ayat (2b) bagian (xxii) ${ }^{35}$. Dalam hal ini, Yurisdiksi ICC dapat melebar ke kasus-kasus di negara yang bahkan tidak meratifikasi Statuta Roma dengan beberapa ketentuan, ketentuan dan kondisi yang dimaksud adalah

1. Kasus tersebut diserahkan dari Dewan Keamanan PBB kepada ICC.

2. Negara pihak ke-3 dalam suatu kasus melakukan kejahatan internasional di wilayah negara anggota statuta roma yang mengakui yurisdiksi ICC.

i. Negara pihak ke-3 setuju untuk dilakukan pelaksanaan yurisdiksi ICC di wilayahnya berkaitan dengan kejahatankejahatan tertentu

iv. Pembayaran ganti rugi/kompensasi terhadap korban (Victim Trust Fund)

Menurut hukum HAM internasional, terdapat hak untuk mendapatkan pemulihan kepada korban, salah satunya ialah kompensasi ${ }^{36}$. Statuta Roma memberikan 2 pilihan dalam melakukan pembayaran kompensasi kepada korban, yaitu melalui pembayaran secara langsung dari terdakwa yang diadili, atau melalui pemberian dana perwakilan untuk para korban/Victim Trust Fund (VTF) . ICC dapat memberikan ganti rugi kepada para korban melalui pembayaran denda atau penebusan langsung dari para terdakwa ataupun melalui VTF. VTF ini dapat didapatkan melalui kontribusi secara sukarela. Kontribusi secara sukarela ini merupakan sumber yang sangat penting bagi pembayaran kompensasi kepada

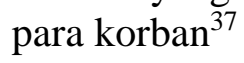

\footnotetext{
${ }^{34}$ Lihat, Pasal 7 ayat (1) g menyatakan: "For the purpose of his Statute 'crime against humanity' means any of the following acts when committed as part of a widespread or systematic attack directed against any civilian population, with knowledge of the attack: ... $(g)$ Rape, sexual slavery, enforced prostitution, forced pregnancy, enforced sterilization, or any other form of sexual violence of comparable gravity", dalam, Op. Cit., Article. 7 Par. (1) g

${ }^{35}$ Lihat, "The court shall have jurisdiction in respect of war crimes in particular when committed as part of a plan or policy or as a part of a large-scale commision of such crimes. For the purpose of this statue "war crimes" means : (xxii) Commiting rape, sexual, slavery, enforced prostitution, forced pregnancy, ... enforced sterilization, or any other form of sexual violence also constituting a grave breaches of the Geneva conventions", dalam, Op. Cit., Article. 8, Par. (2b).

${ }^{36}$ CF. Redress. "The International Criminal Court's Trust Fund for Victims: Analysis and Options for the Development of Further Criteria for the Operation of the Trust Fund for Victims". 2003, hlm. $19-20$.

${ }^{37}$ International Criminal Court, Trust Fund for Victims, Situation of Contributions and Pledges to the Trust Fund for Victims as of 22 January 2007, dalam http://www.icc-cpi.int/vtf.html diakses pada 2 Februari 2022.
} 
c) Pada Tahap Responsibility to Re-Built

i. Pembangunan Perdamaian Pasca Konflik (Post-conflict peace building)

Menurut Sekretaris Jenderal dalam laporannya tahun 1998, Pembangunan perdamaian sendiri bertujuan untuk membangun, menambah, ataupun mengarahkan kembali kegiatan tersebut dengan melakukan rekonsiliasi, rekonstruksi, dan pemulihan terhadap negara yang telah mengalami konflik bersenjata internasional ${ }^{38}$. Pada pemerkosaan yang terjadi di tengah konflik bersenjata internasional, pembangunan perdamaian yang dapat dilakukan meliputi penciptaan atau penguatan lembaga-lembaga nasional, penyediaan program reintegrasi dan rehabilitasi, serta diciptakannya kondisi untuk melanjutkan pembangunan

ii. Perintah kepada negara untuk mereformasi sistem hukum yang timpang gender dan tidak melindungi keselamatan warga sipil, dengan cara meratifikasi konvensi-konvensi terkait

Gagasan ini didukung dari hasil konferensi Inter-Parliamentary Union (IPU) ke-128 Tahun 2013. Poin ke-7 dari hasil konferensi IPU ini menyerukan dan mendesak parlemen dari negara-negara anggota untuk mereformasikan hukum yang mengakomodasikan jaminan perlindungan pada perempuan dan anak-anak, serta mendesak parlemen-parlemen meratifikasi konvensi-konvensi terkait, seperti Statuta Roma ${ }^{39}$

iii. Melakukan reformasi terhadap organ militer negara melalui DDR (Disarmament, Demobilization, Reintegration)

DDR adalah program yang disebutkan dalam article 5.9 Laporan ICISS tentang R2P ${ }^{40}$. Yakni, Pertama, pelucutan senjata (disarmament) bagi para kombatan. Gunanya ialah menekan peredaran senjata api dalam proses pembangunan kembali negara pasca konflik. Kedua, demobilisasi (demobilization). Gunanya ialah mengembalikan pasukan kombatan ke daerah/negara asal masingmasing. Ketiga, Reintegrasi (reintegration). Gunanya ialah membaurkan kembali eks kombatan ke dalam masyarakat.

iv. Memberikan bantuan internasional untuk pemulihan kesehatan fisik dan mental para korban.

Dalam hal ini, Resolusi $2106(2013)^{41}$ Dewan Keamanan PBB mengakui pentingnya menyediakan bantuan yang tepat waktu kepada para penyintas kekerasan seksual, mendesak organ-organ di bawah PBB untuk memberikan layanan kesehatan yang nondiskriminatif dan komprehensif, termasuk kesehatan seksual dan reproduksi, psikososial, hukum, dan mata pencaharian dukungan

\footnotetext{
${ }^{38}$ UN General Assembly, General Assembly - Report of the Secretary-General on the work of the Organization, the causes of conflict and the promotion of durable peace and sustainable development in Africa, 13 April 1998, A/52/871-S/1998/318.

${ }^{39}$ Inter-Parliamentary Union, "Enforcing the Repsonsibility to Protect: The Role of Parliament to Safeguarding in Civilians Lifes", <https://r2pasiapacific.org/files/328/IPU-resolution-enforcingR2P-bahasa-indonesia.pdf>, diakses pada 3 Februari 2022.

${ }^{40}$ Internal Commission on Intervention and State Sovereignty (ICISS), The Responsibility to Protect, Report of the International Commission on Intervention and State Sovereignty, Articles 5.9, 11 Desember 2001.

${ }^{41}$ UN Security Council, Security Council resolution 2106 (2013) [on sexual violence in armed conflict], 24 June 2013, S/RES/2106.
} 
dan layanan multi-sektoral lainnya untuk para penyintas kekerasan seksual, dengan mempertimbangkan kebutuhan spesifik para penyandang disabilitas ${ }^{42}$

\section{SIMPULAN DAN SARAN}

\section{A. Kesimpulan}

Perlindungan wanita dari perkosaan di tengah konflik bersenjata Internasional sejatinya telah diatur secara eksplisit pada Pasal 27 alinea kedua Konvensi Jenewa ke-4, Pasal 75 ayat (2) huruf b dan Pasal 76 ayat (1) Protokol Tambahan I Tahun 1977. Di samping itu, demi membantu penegakan hukum regulasi tersebut, Dewan Keamanan Perserikatan Bangsa-Bangsa telah mengadopsi Resolusi 1820, 1325, dan 2106 yang memerintahkan kepada seluruh negara untuk memastikan telah terpenuhinya hak perempuan dalam konflik bersenjata internasional, dan memerintahkan kepada negara anggota untuk mengupayakan secara maksimal pemberian perlindungan terhadap perempuan saat konflik bersenjata berlangsung ataupun pasca konflik. Selain telah adanya regulasi dan diadopsinya 2 resolusi oleh Dewan Keamanan Perserikatan Bangsa-Bangsa.

\section{B. Saran}

Rekomendasi terhadap PBB dalam memberikan perlindungan terhadap wanita dari perkosaan di tengah konflik bersenjata Internasional adalah dengan memerintahkan kepada seluruh negara di dunia, Komunitas Internasional, dan anggota Perserikatan Bangsa-Bangsa untuk menerapkan norma Responsibility to Protect yang tercantum dalam Pasal 138, 139, dan 140 Dokumen Hasil Konferensi Tingkat Tinggi (KTT) Dunia tahun 2005, dimana di dalam norma Responsibility to Protect ini, negara dibebankan tanggung jawab untuk melakukan upaya untuk mencegah (Responsibility to Prevent), bereaksi / merespon (Responsibility to React), dan membangun kembali (Responsibility to Re-build) terhadap seluruh kejahatan kekejaman massal yang terjadi di tengah konflik bersenjata Internasional.

\section{DAFTAR PUSTAKA}

\section{Buku}

Bellamy, A.J. \& Dune, T. (2016). The Oxford Handbook of The Responsibility to Protect. Oxford University Press.

Breaky, Hugh, Dr Angus Francis, Professor Vesselin Popovski, dkk. (2012). Enhancing Protection Capacity: Policy Guide to the Responsibility to Protect and the Protection of Civilians in Armed Conflicts. Policy Guide.

Evans, J. Gareth, dan Mohammed Sahnoun. (2001). The Responsibility to Protect: Report of the International Commission on Intervention and State Sovereignty. The International Development Research Centre.

Mahkamah Agung Republik Indonesia, (2006), Pedoman Unsur-unsur Tindak Pidana Pelanggaran Hak Asasi Manusia Yang Berat Dan Pertanggungjawaban Komando.

\footnotetext{
${ }^{42}$ dr. Denis Mukwege Foundations, "From victim to survivor: holistic care as a human rights standard and a condition for women's rights", <https://www.mukwegefoundation.org/wpcontent/uploads/2019/04/CSW-statement-DM-RLA-final.pdf>, diakses pada 4 Februari 2022.
} 
Ramadhany, D., Triyana, H J., dkk. (2015). Konteks dan Perspektif Politik Terkait Hukum Humaniter Internasional Kontemporer. Jakarta: PT Raja Grafindo Persada.

Sunggono, B. (2003), Metodologi Penelitian Hukum. Jakarta: Raja Grafindo Persada.

Thomas Ramopoulos, (2015), "International Law and the Application of Third Pillar Approach", hlm. 11. dalam Daniel Flott dan Joachim Koops, "The Responsibility to Protect and the Third Pillar: Legitimacy and Operationalization" (eds), New York: Palgrave Macmillan..

\section{Pranala Luar}

Global Centre For The Responsibility to Protect. (2019). What Is R2P?. Retrieved from https://www.globalr2p.org/what-is-r2p, diakses 28 Januari 2022.

International Criminal Court. (2007). Trust Fund for Victims, Situation of Contributions and Pledges to the Trust Fund for Victims as of 22 January 2007. Retrieved from http://www.icc-cpi.int/vtf.html, diakses pada 2 Februari 2022

United Nations Development Programs. (2011). Gender Equality and Democratic Government.

https://www.eurasia.undp.org/content/rbec/en/home/genderequality/democratic-governance.html, diakses 3 Februari 2022.

Inter-Parliamentary Union. (2013). Enforcing the Repsonsibility to Protect: The Role of Parliament to Safeguarding in Civilians Lifes. Retrieved from https://r2pasiapacific.org/files/328/IPU-resolution-enforcing-R2P-bahasaindonesia.pdf, diakses pada 3 Februari 2022.

dr. Denis Mukwege Foundations. (2019). From victim to survivor: holistic care as a human rights standard and a condition for women's rights. Retrieved from https://www.mukwegefoundation.org/wp-content/uploads/2019/04/CSWstatement-DM-RLA-final.pdf, diakses pada 4 Februari 2022

\section{Prosiding}

Dewi, O.M.. Analisis Penerapan Responsibility to Protect (R2P) dalam Penyelesaian Krisis Kemanusiaan di Rakhine: Studi Kasus Rohingya (2012-2017). Universitas Islam Indonesia, (2018).

Jurnal

Akande, D, The Jurisdiction of International Criminal Law Count Over National of Non- Parties: Legal Basis and Limits. Journal of International Criminal Justice, 1(3). (2003).

Bellamy, J. Alex, dan Ruben Reike,"The Responsibility to Protect and International Law", Global Responsibility to Protect (2), (2010).

Bond, Jennifer dan Laurel Sherret, "A Sight for Sore Eyes: Bringing Gender Vision to the Responsibility to Protect Framework", United Nations International Research and Training Institute for the Advancement of Women, (2006).

Redress, CF, “The International Criminal Court's Trust Fund for Victims: Analysis and Options for the Development of Further Criteria for the Operation of the Trust Fund for Victims". Discussion Document. (2003).

Hilda. Perlindungan Hukum Humaniter Terhadap Perempuan dari Kekerasan Seksual dalam Sengketa Bersenjata. Syiar Hukum. 12 (2), (2010).

Putri, L. H, Responsibility To Protect Sebagai Doktrin Atau Norma Yang Berkembang Dalam Hukum Internasional. Kanun: Jurnal Ilmu Hukum, 17(1), (2015). 
Subono, N. I, Konflik Bersenjata Kekerasan Militer dan Perempuan (Perempuan di Wilayah Konflik). Jurnal Perempuan Yayasan Jurnal Perempuan, Jakarta, (2002).

Teo, Hsu-Ming, The Continuum of Sexual Violence in Occupied Germany, 194549. Women's History Review, 5 (2). (1996).

Peraturan Perundang-Undangan

International Committee of the Red Cross (ICRC), Protocol Additional to the Geneva Conventions of 12 August 1949, and relating to the Protection of Victims of International Armed Conflicts (Protocol I), 8 June 1977, (1977).

International Committee of the Red Cross (ICRC), Geneva Convention Relative to the Protection of Civilian Persons in Time of War (Fourth Geneva Convention), 12 August 1949, 75 UNTS 287, (1949).

UN General Assembly, Rome Statute of the International Criminal Court (last amended 2010), 17 July 1998, (1998).

UN General Assembly, General Assembly - Report of the Secretary-General on the work of the Organization, the causes of conflict and the promotion of durable peace and sustainable development in Africa, 13 April 1998, A/52/871-S/1998/318, (1998).

UN General Assembly, Implementing the responsibility to protect : report of the Secretary-General, 12 January 2009, A/63/677 (2009).

UN General Assembly, Responsibility to protect: timely and decisive response Report of the Secretary-General, 25 July 2012, A/66/874-S/2012/578 (2012).

UN Security Council, Security Council resolution 1325 (2000) [on women and peace and security], 31 October 2000, S/RES/1325 (2000) .

UN Security Council, Security Council resolution 1820 (2008) [on acts of sexual violence against civilians in armed conflicts], 19 June 2008, S/RES/1820 (2008).

UN Security Council, Security Council resolution 2106 (2013) [on sexual violence in armed conflict], 24 June 2013, S/RES/2106 (2013) 